\title{
"Humanizing an inevitability political craft": Introduction to the special issue on archiving activism and activist archiving
}

\author{
Andrew Flinn ${ }^{1} \cdot$ Ben Alexander ${ }^{2,3}$
}

Published online: 20 October 2015

(C) Springer Science+Business Media Dordrecht 2015

\begin{abstract}
The archivist, even more than the historian and the political scientist, tends to be scrupulous about his neutrality, and to see his job as a technical job, free from the nasty world of political interest: a job of collecting, sorting, preserving, making available, the records of the society. But I will stick by what I have said about other scholars, and argue that the archivist, in subtle ways, tends to perpetuate the political and economic status quo simply by going about his ordinary business. His supposed neutrality is, in other words, a fake. If so, the rebellion of the archivist against his normal role is not, as so many scholars fear, the politicizing of a neutral craft, but the humanizing of an inevitably political craft (Zinn 1977).
\end{abstract}

This special issue of Archival Science "Archiving Activism and Activist Archiving" examines the intersections between contemporary archival practice and activism in different national, political, socio-economic, technological, archival settings, and inspired by a variety of motivations and objectives. The practices examined in these articles go beyond advocacy for more active archival approaches and incorporate the spaces and endeavours where archivists seek to creatively document political and social movement activism as well as those projects which engage with archives and the archival process as part or in support of political, human right and social movement activism.

Andrew Flinn

a.flinn@ucl.ac.uk

Ben Alexander

balexand@stanford.edu

1 Department of Information Studies, University College, London, London WC1E 6BT, UK

2 American Studies Center, Sichuan University, 29 Wangjiang Road, 610064 Chengdu, China

3 Director, American Century Project in Department of English, Stanford University, Stanford, USA 
These practices are of course not new. Howard Zinn's, the radical historian, 1970 appeal to archivists and historians to "humanize" their craft by rejecting the "fake" neutrality of professional discourse and in refusing "to be instruments of social control in an essentially undemocratic society, to begin to play some small part in the creation of a real democracy" remains an important reference point over 40 years later. Debates about favouring an open advocacy of political commitment over a studied political neutrality so clearly articulated by Zinn have remained current and contested within the archive profession ever since [see, for instance, the exchange between Greene (2013), Jimerson (2013) and Caswell (2013)].

Zinn's appeal for archival "rebellion" was interpreted most straightforwardly, and indeed was initially framed thus by Zinn himself, as a call for more active and creative approaches to archival practice (Ham 1975; Quinn 1977) including supporting greater governmental openness and orientating institutional mandates towards creating more socially representative collections. However the thrust of Zinn's argument, the recognition of the potential significance of archives and archival processes within a range of different political and social movement campaigns, was also activated by contemporary independent and community-based archival initiatives launched in the 1960s and 1970s which documented and engaged with the histories and ongoing struggles of women and working-class organizations, and for gay liberation and civil rights. In these endeavours, archive materials were used as sources documenting and memorializing past struggles and violations of rights, as resources supporting ongoing claims for justice and healing, and as tools for understanding the past in order to influence the present and the future. Writing at the end of the 1970s, the Swedish author and activist Sven Lindqvist believed that it was essential for workers to understand their history, to "dig where you stand" because "History is important because the results of history are still with us...History is still paying dividends. History is still conferring power on people" (Lindqvist 1979, 30).

Subsequent powerful and influential arguments concerning the complex, socially contested cultural and historical matrices within the archive and their production of political agency and the exercise of power by the likes of Jacques Derrida (1996) (not least the oft-referenced observation that, "[t]here is no political power without control of the archive, if not of memory") and archival writers such as Schwartz and Cook (2002) stimulated a deep and abiding fascination in "the archive" and those that engage with archives. Hindsight, however, confirms that these works are themselves situated in the chronology of scholarly investigation focusing on critical junctures between the archive as places "where complex processes of "remembering' occur, creating and recreating certain kinds of social knowledge" and also where essential processes of shaping historical identity into political agency fully manifest (Blouin and Rosenberg 2006, vii).

Taken as a whole, this body of "archival turn" work offers multiple points of entry into archival and political discourses that seek to provide sensitive perspectives on processes of the historicization of social and political instabilities (such as the end of colonial subjugations and the rise of civil rights and other social movements aiming at the transformation of society). These perspectives were in part shaped by an archival environment that had witnessed a blossoming of autonomous, 
creative and community-based archival activity that suggested a revaluation of the fundamental influence of the archive as equal parts historical repository and agent of political representation.

These debates and developments took place against the backdrop of social and cultural change emanating from new contestations of history, memory, identity and political authority that arose from the (sometimes unrealized) democratization of the very technologies of capture and contextualization of history itself. These new historical matrices were themselves embedded in digital matrices that when combined offered potentially transformative opportunities for a less mediated documentation and collection of memory. These new possibilities have been employed by archivist-activists and activist-archivists both as strategies of resistance and contestation, and as the basis for subsequent curations which serve as agents of political authority.

Although all the articles collected in this issue could be characterized as describing endeavours broadly associated with the political "left" or at least some "progressive" articulation of social justice, democracy and human rights, and we as guest editors make no apology for that orientation, it is important to note three obvious but significant points in response. First the use of archives and engagement with archives is by no means confined to civil rights and social justice movements but can equally be identified within other, predominantly right-wing or conservative, movements also seeking to document the past to impact the present and the future. Second, it is of course clear in the arguments made by Zinn and others that it is not just those adopting an explicit activist archival approach who are acting politically, but the state and those who serve it are also pursuing an intensely political project which seeks to perpetuate "the political and economic status quo". Finally, while we would certainly accept that, like the national archival frameworks and the narratives that they sustain, these activist projects are contestable and indeed frequently are contested, and although they may be flawed and exclusive, their very existence and influence further demonstrates the potentiality of archives and of the past (often a "useful past") in engaging with the present and seeking to influence the future.

A final word on definitions. The practices described in this issue are associated with a confusion of compound terms combining active, activism and archives, and the meanings of these are not fixed or widely agreed. We would like to address this by outlining our understanding of these frequently overlapping activities and approaches. First, an active archivist or active archiving describes an approach to archival practice which, rejecting professional advocacy of neutrality and passivity, acknowledges the role of the recordkeeper in "actively" participating in the creation, management and pluralization of archives and seeks to understand and guide the impact of that active role. Second archiving activism describes an archivist or archival institution, whether formal or independent, acting to collect and document political, social movement and other activist groups and campaigns. Archival activism describes activities in which archivists, frequently professionally trained and employed but not exclusively so, seek to campaign on issues such as access rights or participatory rights within records' control systems or act to deploy their archival collections to support activist groups and social justice aims. Finally, 
activist archiving describes the processes in which those who self-identify primarily as activists engage in archival activity, not as a supplement to their activism but as an integral part of their social movement activism.

As the articles in this special issue make abundantly clear, in offering these descriptions we realize that these definitions are not fixed, and that there are no clear binary distinctions between activists and archivists, between archiving and activism, and between active and neutral. In fact, these articles illustrate the many overlaps and different approaches adopted, sometimes simultaneously, by those engaged in these activities. Nevertheless, we do believe that there is value in trying to identify and clarify some distinctions in the nexus of archives and activism.

As we have already acknowledged, the explicit alignment with political activism and social justice objectives has its critics within the recordkeeping profession, but activist archival approaches go beyond the necessity of being and advocating for an "active archivist" and instead embrace a view of archival practice as a form of social, cultural and political activism. Although not necessarily synonymous, activist archiving and archival activism approaches intersect with other contemporary archival debates about more creative, collaborative and participatory recordkeeping practices, especially with regard to furthering human rights agendas (Gilliland and McKemmish 2014). Both perhaps share an understanding of the power of the democratization of knowledge creation and the potentialities of new technologies to enable that democratization.

The purpose of this special issue is to add twenty-first century reflection to the more than four decades of historiographical discourses and archival activist practice concerning the archive and its political agency. The articles collected here contribute a critical perspective which addresses what we feel to be some of the key professional concerns of our time. These include the challenges of defining the nature of the archive in the twenty-first century, of using digital matrices as a strategy to activate "passive" memory, of creating archival practice and systems which embed thorough-going community-orientated or community-based participatory approaches, and of curating an "activist archive" with the intention of preserving (and maintaining political relevance) past "social movement cultures" in the present and future.

The articles included here offer five different approaches to archiving activism and activist archiving, but this is by no means a comprehensive overview. Each account indicates the strength and plurality of the field, the variety of the approaches undertaken, the meaninglessness of some of the boundaries we seek to maintain (professional versus non-professional, activist versus archivist) as well as the many absences from the discussions compiled here. Space was a constraint; as editors we received many more submissions than we had pages available for this special issue, the lack of explicit discussion of feminist, queer, racial or ethnic archives being only the most obvious omissions.

All the articles in this collection offer concrete, real-world case studies of wellcontextualized and sensitive articulations of archivists' activist responsibilities in curating and enabling the transformation of sometime distant and "passive" memory into active political agency. Taken together, these articles are notable for making the case for advocating greater participatory practice in archival processes 
within an activist context, of dissolving the boundaries between curator and user and in particular for advancing the claims for archival "self-determination" of those doubly impacted by historical abuses and the subsequent contested and inadequate histories that document those abuses through a combination of ethical mediation and a transformed archival practice reflecting a deeply embedded orientation towards community participation.

In their article, Joanne Evans, Sue McKemmish, Elizabeth Daniels and Gavan McCarthy build on a critical analysis of case studies of the experiences in Australia and elsewhere of children in out-of-home "care" to argue that traditional archival and recordkeeping practices operate in a systemic way to impede social justice, facilitate human rights abuses and "perpetuate harm and inequality". They argue that for this to change and to win the argument for a radically transformed recordkeeping practice which seeks to empower those communities pursuing social justice and human rights agendas with agencies in the recordkeeping, archiving and memory making process, activist recordkeepers need to engage in broad social movement campaigns at the highest level. This archival activism means advocacy not just in the workplace and in the profession but as part of a sustained campaign at the highest level in society.

Like Evans, McKemmish et al., the article by Amanda Strauss contends that in the context of extreme violations of civil and human rights and a deeply contested national memory, "inaction causes harm" and archival neutrality "becomes an untenable position". The article examines the archival activist approaches undertaken by archivists and human rights activists in Chile with regard to the documenting and remembering of the human and civil rights abuses perpetuated under the Pinochet dictatorship. Strauss applies a definition of social justice rooted in liberation theology to an archival activism which utilizes the documentation of human rights abuses created at the time of dictatorship to ensure the abuses, the victims and survivors and their perpetrators are remembered and that those documented memories are recognized and acknowledged in the public arena. In common with other articles here Strauss argues that in the context of archival activism and activist archiving, binary divisions between archivists and activists dissolve and the archive is not a "temple" but instead a participatory "common ground".

Many of the archival activist/activist archiving projects described here are multilayered with many different components and objectives. Sonia Yaco, Ann Jimerson, Laura Caldwell Anderson and Chanda Temple's article draws upon case studies of their work with the Kids in Birmingham 1965 and Desegregation of Virginia Education projects to describe the development of digital communityorientated hybrid archives as a toolkit for a "model for community-building projects using archival documentation, oral history, and community participation". The projects described in this article seek with a clear activist motivation to document and address questions of the historical understanding and ongoing impacts of racial discrimination, segregation and civil rights struggles in the USA in the 1960s. They do so by actively enabling previously absent storytellers to contribute their own personal testimonies (including those the authors describe as the "passive participants" as well as more activist accounts) and then via a digital platform 
actively sharing the archive with a range of stakeholders (community members and organizers, archives and other cultural heritage institutions, educators and students, and the media) in order to inspire further debate, reflection and acknowledgement of injustice and to promote future change.

Alexandrina Buchanan and Michelle Bastian continue the exploration of the impact of archives and historical research in an activist context, in a very "Dig Where You Stand" fashion. Their article describes a collaborative research project, Memories of Mr. Seel's Garden which brought together academics, heritage professionals and community groups to explore how community participation in locally grounded historical research including exposure to "traditional" (i.e. not created or selected as explicitly activist) archival material could affect participants and inform a more sophisticated, "imaginative and creative" current and future activist practice, in this case local food activism.

The final article comes from Alycia Sellie, Jesse Goldstein, Molly Fair and Jennifer Hoyer of Interference Archive, a new archival space designed as a "living archive" and repository of activist initiatives which predicates its practice on democratic and participatory approaches involving the archive and its users. The authors describe Interference Archive as being "grounded geographically" but "nonetheless situated at the interstices of a wide variety of global and networked communities". In this regard, the archive represents a collective agency, a postOccupy view of political action as networked, collective and seeking to transcend the bifurcations of race, class, gender that individualized civil rights movements dating from the middle of twentieth century. The relationship between communitybased archives and activist archives and once again the necessity of seeing beyond the narrow binaries of community versus institutional, professional versus activist, and archive versus activist resource is central to this account. As activists as well as professional trained archivists and librarians, the authors are both observers and participants able to contrast the sometimes fruitful, sometimes contentious process of archiving activism in formal institutions with activist archival practices in social movement contexts. Significantly, they, like many other writers and activists, stress the importance of the activist archive as a "free space" and shared "social centre", a scarce transmovement and prefigurative resource in which, following Francesca Polletta, different communities can meet and share, new networks of solidarity can be forged, and acts of new cultural production and activism can be planned and enacted.

We conclude this introduction by returning once again to Howard Zinn speaking to American archivists in 1970:

Scholarship in society is inescapably political. Our choice is not between being political or not. Our choice is to follow the politics of the going order, that is, to do our job within the priorities and directions set by the dominant forces of society, or else to promote those human values of peace, equality, and justice, which our present society denies (Zinn 1977)

and linking these sentiments with those expressed by the activist-archivists of Interference Archive over 40 years later: 
It is not our desire to take on an objective position when it comes to telling our histories, and this informs our archival practices as well-in terms of what is collected and saved, how it is described, and how it is made accessible. We are building Interference Archive as a consciously political space in which to do this work, without the guise of professional neutrality. Together we are creating a space for our collective memory. We hope to preserve this history to which we are all indebted, and that we continue to define (Fair 2014, 190).

Acknowledgments The editors of this special issue would like to thank all those who submitted articles to this issue, those who have found a place here and all those who have (hopefully) found a place elsewhere. We are sorry that we could not publish more. We would also like to thank very much all the editors and editorial support at Archival Science and Springer for their patience and perseverance in guiding this issue to publication.

\section{References}

Blouin F, Rosenberg W (eds) (2006) Archives, documentation and institutions of social memory. Essays from the Sawyer Seminar. University of Michigan Press, Ann Arbor

Caswell M (2013) Not just between us: a riposte to Mark Green. Am Arch 76(2):604-606

Derrida J (1996) Archive fever: a Freudian impression. University of Chicago Press, Chicago

Fair M (2014) Building an archive from below: reflections from the Interference Archive. In: Morrone M (ed) Informed agitation. Library and information skills in social justice movements and beyond. Library Juice Press, Sacremento, pp 185-190

Gilliland A, McKemmish S (2014) The role of participatory archives in furthering human rights, reconciliation and recovery. Atlanti 24(1):79-88

Greene M (2013) A critique of social justice as an archival imperative: What is it we're doing that's all that important? Am Arch 76(2):302-334

Ham G (1975) The archival edge. Am Arch 38(1):5-13

Jimerson R (2013) Archivists and social responsibility: a response to Mark Greene. Am Arch 76(2):335-345

Lindqvist S (1979) Dig where you stand. Oral Hist 7(2):24-30

Quinn P (1977) The archivist as activist. Ga Arch 5(1):25-35

Schwartz J, Cook T (2002) Archives, records, and power: the making of modern memory. Arch Sci 2:1-19

Zinn H (1977) Secrecy, archives, and the public interest. Midwest Arch 2(2):14-26 